Western University Scholarship@Western

Centre for the Study of International Economic

Centre for the Study of International Economic

Relations Working Papers

Relations

1985

\title{
A Microconsistent Data Set for Canada for Use in Regional General Equilibrium Policy Analysis
}

France St-Hilaire

John Whalley

Follow this and additional works at: https://ir.lib.uwo.ca/economicscsier_wp

Part of the Economics Commons

Citation of this paper:

St-Hilaire, France, John Whalley. "A Microconsistent Data Set for Canada for Use in Regional General Equilibrium Policy Analysis." Centre for the Study of International Economic Relations Working Papers, 8533C. London, ON: Department of Economics, University of Western Ontario (1985). 
THE CENTRE FOR THE STUDY OF INTERNATIONAL ECONOMIC RELATIONS

WORKING PAPER NO. $8533 \mathrm{C}$

A MICROCONSISTENT DATA SET

FOR CANADA FOR USE IN REGIONAL

GENERAL EQUILIBRIUM POLICY ANALYSIS

\author{
France St-Hilaire \\ and
}

John Whalley

This paper contains preliminary findings from research work still in progress and should not be quoted without prior approval of the author.

DEPARTMENT OF ECONOMICS THE UNIVERSITY OF WESTERN ONTARIO LONDON, CANADA

N6A $5 \mathrm{C} 2$

Department of Economics Library
DEC 41985
Universiby of Westem Ontario




\title{
A MICROCONSISTENT DATA SET \\ FOR CANADA FOR USE IN REGIONAL \\ GENERAL EQUILIBRIUM POLICY ANALYSIS 1
}

\author{
France St-Hilaire \\ and \\ John Whalley
}

November 1985

\begin{abstract}
${ }^{1}$ The work reported in this paper is part of a project on Applied General Equilibrium Analysis supported by the Social Sciences and Humanities Research Council, ottawa. Some of the data has already been used in subsequent work for the Royal Commission on the Economic Union and Development Prospects for Canada and other ongoing modelling work. The authors wish to acknowledge the support of both of these bodies.
\end{abstract}




\section{A Microconsistent Regional Data set for Canada for Use in Counterfactual \\ General Equilibrium Policy Analysis}

\section{Introduction}

In federal countries, such as Canada, a wide range of contentious regional issues frequently enter policy debate. For example, the regional impacts of tariffs, federal taxes and energy price controls and have all been topics of discussion for many years. This paper describes the sources and methods used in assembling a microconsistent regional data set for Canada for 1981 for use in counterfactual general equilibrium policy analyses focussing on regional impacts of these and other policies. We also provide summary tables presenting the main features of this data.

The methodology used follows that presented in an earlier paper of ours (St-Hilaire and Whalley (1983)) which describes the construction of a 1972 national data set for Canada developed for tax policy analysis. The possibility of disaggregating this data set by region was considered at the time of construction, but due to data constraints this issue was left largely unexplored.

A microconsistent data set at the regional level requires assembling detailed consistent accounts of production and demand by region, of interregional and international trade flows and of transactions involving multiple levels of government. For many or most countries, the data requirements associated with 
regional general equilibrium analysis preclude this form of work. But because of the substantial progress made in recent years in developing provincial data sources such as the Provincial input output tables (PIO) and the provincial economic accounts (PEA), the situation is different in Canada. Using these data, it is possible to construct an interregional microconsistent benchmark data set at a suitable level of commodity detail for subsequent model use. This data set has in fact already been used in an initial evaluation of a number of Canadian regional issues (see Trela and whalley (1985)).

The resulting regional benchmark data set differs from previously constructed, and largely tax oriented, microconsistent data sets such as those by St-Hilaire and whalley (1983), Piggott and Whalley (1985), Ballard, Fullerton, Shoven and Whalley (1985) and others, in that it records both transactions between regions, as well as production and demand by commodity at the regional level. The data set also incorporates federal government transactions with individual regions, and policy features such as energy price controls which have been a source of disagreement between energy producing and energy consuming regions in Canada . Also, the problems encountered in assembling this data set are different than those in constructing national data sets. In the latter case, most of the work consists of reconciling and expanding basic input output accounts, using additional information from income and expenditure accounts, balance of payments, financial flows accounts and family expenditure surveys. The 
problem in constructing the present regional data set is the lack of alternative data sources to use to reconcile and expand PIo data. Available provincial data has been adjusted to achieve microconsistency at the level of detail desired, but it is not possible to reconcile all entries in the data set with the existing system of aggregate accounts in the same way as at a national level.

The plan of the paper is as follows. In the next section we outline the structure of the regional data set. What follows is a brief description of the basic data sources and the problems which arise in assembling a regional microconsistent data set using these. We then outline the various adjustments we have made in order to achieve microconsistency. The final section reports summary tables displaying some of the main features of the resulting data.

II. The Structure of the Regional Microconsistent Data Set

In several of the numerical general equilibrium models now in use (see Shoven and whalley (1.984)), a common procedure is to calibrate the model so as to reproduce a base year data observation as an equilibrium solution. specifying the model in this way enables it to be used to compute a counterfactual equilibrium for a policy or other change. The potential impacts of various policy changes can then be evaluated through a comparison of the base year microconsistent data and the new 
equilibrium model solution. This procedure may be thought of as corresponding to comparative static analysis common in theoretical literature.

To implement this approach the equilibrium conditions which characterize the model must hold in the microconsistent data set used in calibration. In the case of a regional general equilibrium model, for which the present data set has been constructed, the value of intermediate and final demands for each commodity produced in each region must equal the value of supply. At an industry level, the value of production by each industry in each region must equal its total cost of production. on the demand side, each region must satisfy its budget constraint. Finally, each region must satisfy an external sector balance condition which takes account of its transactions with other regions, the rest of the world and the federal government. The benchmark regional data set assembled for 1981 satisfies all of these conditions.

In this data set each region, in effect, is treated as a separate economy, although the links between regions differ from those between nations as recorded in international trade data. Commodity trade between regions is only part of each regions' transactions. Payments of federal taxes by regions, intergovernmental and personal transfers received by regions, and federal government expenditures on regional products must also be recorded. As a result, a surplus (or deficit) in transactions with the federal government can finance (or is implied by) a 
deficit (or surplus) in a region's international and interregional trade in commodities.

The data set should also take account of interregional asset ownership and the associated capital income flows. However, this data is unavailable for Canada. Interregional flows of capital income are therefore excluded from the data set under the assumption that the value of capital income originating in any region equals the value of capital income accruing to residents of the region. As a result the microconsistent data, much like the available provincial data sources, is on a "domestic" basis with income allocated to the region in which it is earned.

The structure of the resulting regional data set is perhaps best displayed through a numerical example of interlocking regional accounts such as the one presented in Table 1 . In this example, production and demands by commodity in each region are displayed, along with interregional trade flows and those between the individual regions and the federal government, which purchases regionally produced products. As can be seen, the activities of the federal government affect the budget constraint of each region through federal taxes paid, intergovernmental transfers and transfers to persons, and federal government expenditures on goods produced by the region.

The income and outlay accounts for each region satisfy budget balance conditions (incomes equal expenditures), as does the account for the federal government. The federal government 


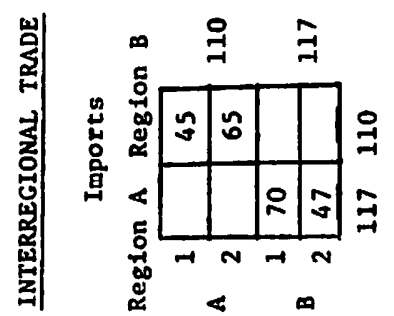

量 国

㟔

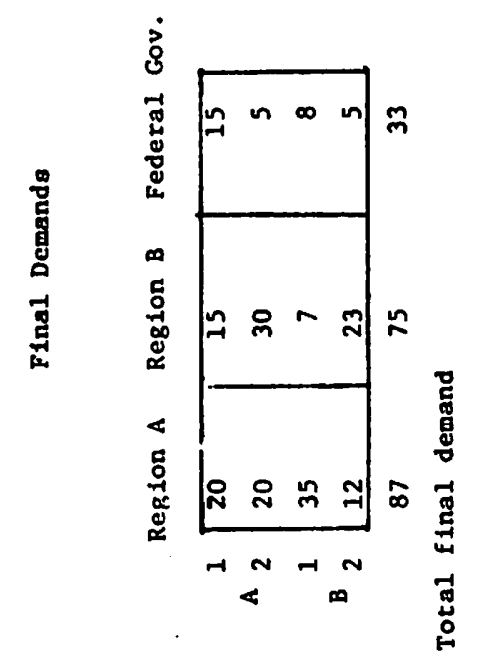

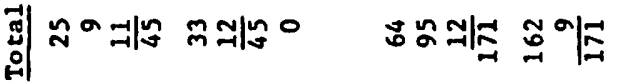

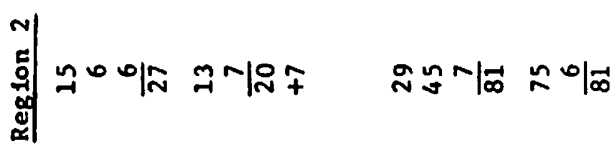

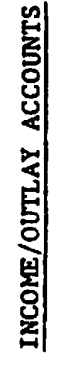

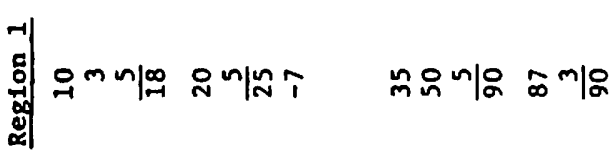
岁苍

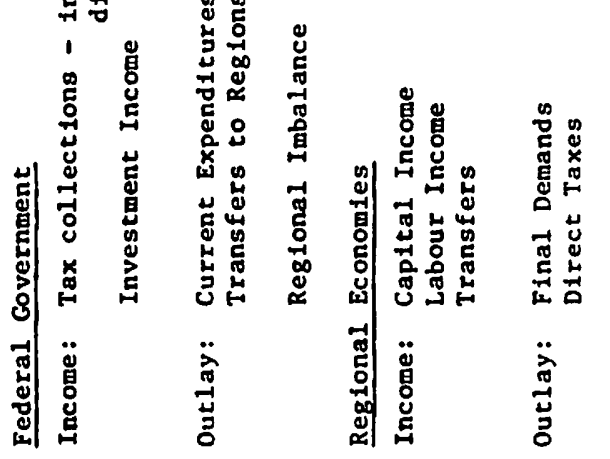

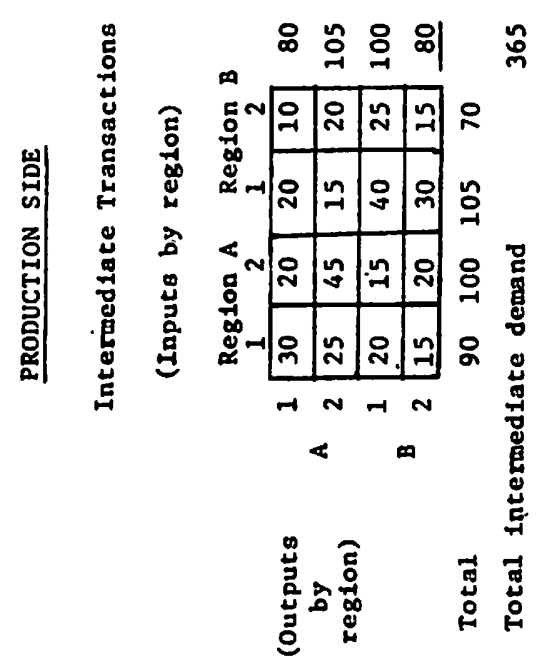

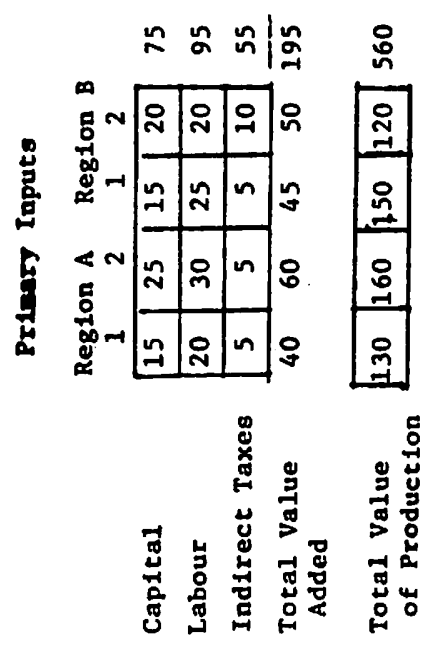


6

surplus or deficit with individual regions reflects the difference between taxes and investment income originating in the region on the one hand, and goods purchased from the region and amounts dispersed in transfers on the other. In each region, the federal government surplus or deficit is exactly offset by the region's trade imbalance. No interregional flows of capital income enter either this example or the 1981 microconsistent data set.

III. Basic Data Sources at the Regional Level

In constructing a microconsistent data set to be used in a regional general equilibrium model, all the transactions taking place in the separate markets and regions which comprise the national economy must be taken into account. The Provincial input-output accounts prepared by statistics Canada as part of the system of National Accounts are the most detailed set of regional production and expenditure accounts available for Canada and the only data upon which to base such a framework. These provincial tables have been prepared by statistics Canada for 1974 and 1979 as an extension of their national model. The 1979 tables provide the main input for the regional data set described in this paper.

The PIo Tables are similar in structure to economy-wide Input-output Tables. They contain two sets of interrelated provincial accounts--a set of commodity accounts reporting the supply of and the demand for individual commodities produced in 
provinces--and a set of industry accounts showing the gross output of each industry, along with each industry's inputs.

In the first set of accounts, the supply of each commodity is reported as the amount produced by each industry in the province, plus the amount imported by the province. The demand for each commodity is reported as the amount used by each provincial industry plus the amount purchased by the final demand sectors in the province, and the amount exported. In the second set of accounts the gross output of each industry in the province is shown by commodity. The inputs used by each industry are reported by commodity, and by type for the primary inputs (i.e.. indirect taxes, wages and salaries, and capital use costs). For each industry in each province, total production costs (value of intermediate plus primary inputs) equal the value of total production.

Data on interprovincial and international trade flows appear separately. Trade flow matrices record commodity trade between the various provinces, and between provinces and the rest of the world.

The provincial input-output accounts are still at a developmental stage. In contrast to national input-output tables, where demand supply equality conditions for each commodity implicitly hold, currently available provincial tables do not satisfy such conditions, mainly due to a lack of data on changes in inventories by commodity by province. Also, while the national inputoutput tables are typically consistent with published measures of 
gross domestic product and expenditure at market prices from national Income and Expenditure Accounts, the PIO data are only constructed using these estimates as a reference point; strict consistency is not ensured. A further problem is the limited amount of information available on interprovincial trade in services. A series of arbitrary assumptions are made in the statistics canada data both regarding the type of services that are traded across provinces, and the interprovincial pattern of flows.

One objective of the modelling exercise for which the data set has been developed was to provide regional policy evaluations for a recent year, preferably following the major policy initiatives undertaken in 1980. A joint evaluation of the modelling objectives and data constraints resulted in 1981 being chosen as the benchmark year for the data set. This, however, required that the 1979 PIO data be updated to 1981 using regional aggregates from the Provincial Economic Accounts (PEA). The PEA also provide the data on federal government transactions with individual provinces which are integrated into this 1981 data set.

The PEA have been available longer than PIO data, and are currently published for the years 1966-1981. However, these data remain officially described as experimental and subject to revision either for conceptual or other reasons. In contrast to Canadian National Income and Expenditure Accounts data which are estimated on a national basis, i.e., with incomes assigned 
according to the residence of the owners of factors of production, the PEA are estimated on a domestic basis, allocating income to the region in which it is earned. This approach, necessitated given data avalability, is also used in determining the location of activities involving the federal government and multiprovincial corporations.

The PEA data are not as comprehensive as the National Income and Expenditure Accounts. The emphasis in developing these accounts has been on producing estimates of gross provincial product and expenditure, and government revenue and expenditure accounts for each of three levels of government as they affect each province (federal, provincial, and municipal). Data on transactions by type and by sector within each province necessary to construct sectoral income and outlay accounts or to revise national account based value added estimates by industry, as in the earlier national microconsistent data set, are not yet available. A further problem with these accounts is that net exports by province are estimated by residual estimates when balancing gross provincial product and expenditure accounts. While these do provide a measure of the trade imbalance in goods and services for each province, they inevitably include a significant residual error component.

All of these data considerations must also be taken into account in evaluating the reliability of the benchmark microconsistent regional data set assembled from these basic data sources. 
IV. Adjustments, Modifications and Extensions of Basic Data Sources

To produce the regional microconsistent data set for the 1981 base year, a series of adjustments to basic data are necessary. These involve on the one hand, modifications, reclassification and redefinitions of concepts for portions of the 1979 PIO accounts to make the resulting data set compatible with eventual model use and, on the other, the addition of further detail required for the desired policy analyses.

(a) Adapting 1979 Provincial Input-Output Data

The 1979 PIO accounts available from the structural Analysis Division of statistics Canada include, an output matrix recording the production of commodities by industry; a use matrix recording intermediate and primary inputs of industries; and a final demand matrix recording final expenditures for goods and primary inputs by category for each province. Data on both interprovincial and international trade appear in a series of separate flow matrices displaying the trade of each commodity between provinces (imports and exports) and between each of these and the rest of the world.

The level of detail provided includes 51 commodities and primary inputs, 14 final demand categories, and 43 industries in the most comprehensive provincial tables (Quebec and ontario). The industry classification differs slightly across provinces. since certain industrial categories do not appear as producing industries, or are aggregated with others because of their small size. 
The first modification needed is to make the industry classification consistent across all provinces. The PIo data are aggregated to 12 industry and 12 corresponding commodity categories 1 with a thirteenth category added to represent government provided services. This more manageable level of commodity aggregation matches that used in the regional general equilibrium model. The final demand categories are aggregated to represent three sectors: consumer, government and business.

Data on individual provinces are also aggregated to six regions reflecting the regional aggregation in the model in which the data is to be used. These are: Atlantic (East), Quebec, Ontario, Manitoba/Saskatchewan (MAN/SASK), Alberta and British Columbia. Because of their relatively small size, and the similarity of the policy issues between them, the Atlantic provinces are aggregated into one region. This same reasoning also applies to Manitoba and Saskatchewan, with Alberta remaining a separate region because of the importance of energy resources and the related policy issues.

The interprovincial/international trade flow matrices are also made consistent with model classifications. These data are aggregated and combined into a single matrix with 91 rows (representing 13 produced commodities in each of the six regions and the rest of the world) and 8 columns (representing the six regions, the rest of the world, and the federal government).

${ }^{1}$ A description of this commodity and industry classification appears in Appendix A. 
Since the benchmark year chosen for the regional equilibrium model analysis is 1981 , the 1979 PIo tables (the latest estimates available) must be scaled to 1981 using aggregate estimates from the PEA. 1981 to 1979 ratios of gross domestic product and expenditure by region are used to scale both 1979 input-output estimates of primary input use by industry and final demand sectors on the product side, and estimates of final demands by commodity by sector on the expenditure side.

The government sector final demands are then disaggregated to differentiate between federal and regional expenditures, using as weights the ratios of federal to total government expenditures by region calculated from PEA estimates. The estimates of federal government final expenditures by commodity by region appear in the microconsistent data set alongside the interregional trade flows.

The 1981 to 1979 ratios of GDP by region calculated from PEA estimates are also used to scale 1979 interregional trade data. Estimates of imports from the rest of the world and exports to the rest of the world are scaled to 1981 using National Income and Expenditure Accounts data of Canadian international imports and exports for 1981 .

The updated primary input data (value added) are further adjusted to reflect a broader concept of factor income consistent with model use. The resulting data differ substantially from that reported in both the PIO accounts and the PEA: 
- Real depreciation is netted out of both capital income and investment expenditures. 1

- Self-employment income is allocated between the return to capital and return to labour by industry.2

- Property taxes are netted out of total indirect taxes and are treated as a factor tax on capital income.

- Government royalties on natural resources are not recorded as an input purchase into production activity (as in the pIo Tables), but instead are treated as a factor tax on resource income originating in natural resource industries.

- Government capital income and expenditure estimates at the regional and the federal levels include an imputation made to reflect the implicit return from government's ownership of capital stock.

- Value added shown as originating in the personal and government sectors in PIO data is included as part of production activity in the services industries in the regional benchmark data.

Because of the importance of energy issues in canada over the past decade and the fact that this industry has been subject to wide fluctuations in annual production, special efforts have

1 The estimates are based on Capital Consumption Allowance data published in Fixed Capital Flows and Stocks (1983). (1983).

2 Using national estimates from st-Hilaire and whalley 
been made to adjust the input-output and other data to better reflect 1981 energy production costs and output in the regional data set. The microconsistent data set also incorporates additional detail to allow for model analyses of the regional impacts of energy policies, in particular, the 1981 price controls. (See following section).

To improve the treatment of energy in the benchmark data, information published by the Petroleum Monitoring Agency (PMA) has been used to construct an industry-wide income and expense statement for both the upstream (production level) and the downstream (mostly refineries) segments of the industry, and to calculate the net return to the energy industry in each region. These estimates of income along with estimates of corporate income taxes, royalties, and federal sales and excise taxes paid by the energy industry are incorporated in the industries account.

Once the energy industry and the value added data have been adjusted and the input-output estimates are scaled to 1981, a final round of adjustments is required to achieve full microconsistency in the whole data set. This ensures that all required equilibrium conditions of the regional general equilibrium model are also reflected in the microconsistent data set to be used in this model.

The RAS adjustment method is used for this purpose.1 This technique is applied first to the interregional and international

\footnotetext{
${ }^{1}$ see Bacharach (1971).
} 
trade data to ensure that regional external sector balance conditions hold. Each region's imports from other regions and the rest of the world will thus exceed or fall short of its exports to other regions and the rest of the world by the federal government's surplus or deficit with that particular region (as in the numerical example in Table 1). The intermediate demand matrix is adjusted in the same fashion using trade and value added data, along with production and final demand estimates. This ensures that in the final data set, demand is equal to supply for each commodity produced in each region, and total costs equal the value of production for each regional industry.

(b) Incorporating Additional Detail into the Data set

The PEA detailed estimates of revenues and expenditures for all levels of government by province, are integrated into the data set and in certain cases disaggregated further to account for all government transactions. An additional feature of this microconsistent data set is the explicit incorporation of subsidies to energy consumers and taxes on energy producers (both actual and implicit) under the price control regime operating in 1981. The modifications and extensions which have been made to enable specific policy analyses are:

- Indirect taxes paid both by industries and by final demand sectors for 1981 are disaggregated by commodity using tax margins and balance sheet estimates provided by the Inputoutput Division of statistics Canada. 
- Energy indirect taxes, such as the petroleum compensation charge, the natural gas and gas liquids tax and the canadian ownership charge (all of which operated in 1981) can be fully passed on to consumers and are adjusted accordingly. The 1981 PEA 1 regional estimates for these taxes are reallocated using as weights the regional distribution of the imputed subsidy to consumers of crude oil and/or natural gas by region (see below). PEA estimates of oil export taxes by region are included as part of the production taxes of the energy industry.

- The Petroleum and Gas Revenue Tax (PGRT) and government royalties on natural resources are included as part of the energy industry factor taxes. The PGRT estimates are unpublished data provided by the GNP division of statistics Canada, while estimates of royalties are calculated using the PMA survey. The total is allocated using the PEA distribution of royalties by province reported as government investment income.

- Corporate income tax payments by industry by region are calculated using the 1981 industry distribution of federal and provincial taxes paid, reported in Corporation Taxation statistics.

- Labour taxes paid by industry by region (social security and related contributions) are calculated by using the st-

\footnotetext{
${ }^{1}$ See footnote to Table 1 in PEA.
} 
Hilaire-Whalley (1983) estimates of national labour tax rates and scaling to the 1981 PEA totals.

- The data on industry subsidies by region consist, for the most part, of 1979 input-output estimates scaled to sum to 1981 PEA aggregates. However, energy related subsidies are separately identified. Payments to regions under the Petroleum Incentives Program are unpublished data obtained from statistics Canada. Subsidies financed through the Petroleum Compensation Fund are as reported in the PEA, 1 but the oil import subsidy, which in the PEA is allocated by province according to consumption of imported oil, is reallocated using regional data on total energy consumption.

- The energy resource rents originating by province are integrated into the data set. These data are based on published estimates by the Economic Council of Canada $(1982)^{2}$ for 1980 . The reported estimates of rents not collected through energy taxes on producers of crude oil, natural gas and hydro electricity are updated to 1981 and incorporated in the data set as implicit taxes on energy producers and implicit subsidies to energy consumers under the energy price controls in use in 1981.

1see footnote to Table 1 in PEA.

2 See Chapter 4 and Appendix B. An average of the high and low estimates has been used in this case. 
- The PEA estimates of federal and regional personal income taxes, transfers to persons, and intergovernmental transfers reported in the PEA are aggregated by region and included in the benchmark income and outlay accounts. These determine, in part, the regions' budget constraints.

- Given the static nature of the regional general equilibrium model in which the microconsistent data is used, interest on the public debt is treated as a government transfer to the private sector. Repurchase of government debt is netted out of government investment income.

v. Summary Tables from the 1981 Regional Micro-Consistent Data Set for Canada

Some of the key features of the resulting benchmark data set are presented in summary form in Tables 2-5. These display the major characteristics of each of the regional economies in the data set, the degree and form of interdependence among the various regions, the relative importance of their international and interregional transactions, and the federal government's transactions with the regions.

Table 2 reports the aggregated commodity and industry accounts for one of the six regions, Ontario. This table displays the key elements of demand, supply and production which appear for each region, and emphasize the equilibrium conditions characteristic of the data set. In the commodity accounts, for instance, the supply of each ontario product is equal to the value of demand for each ontario product, (the sum of total 

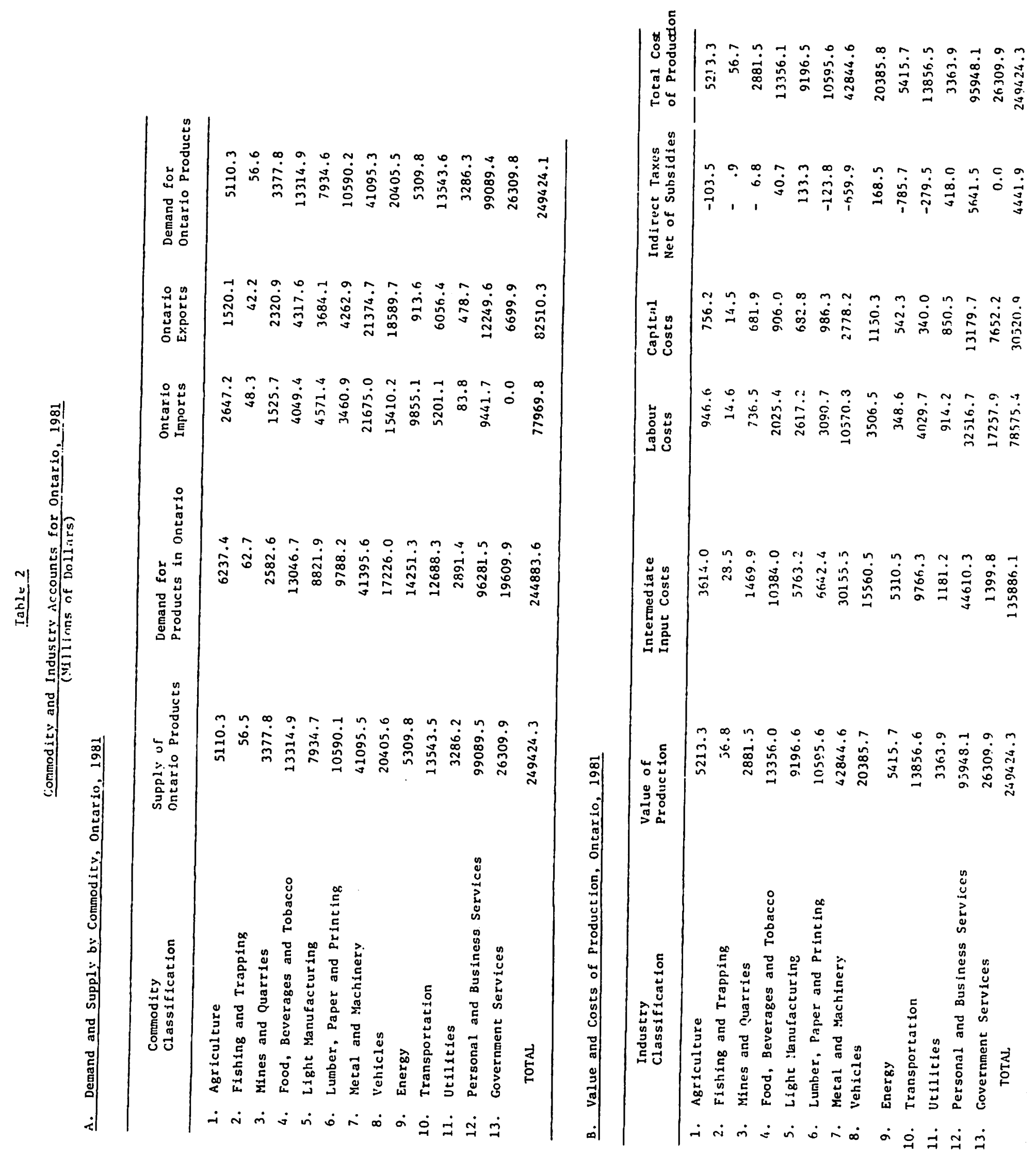
demand in ontario minus the value of ontario imports plus the value of ontario exports). In the industry accounts, zero profit conditions are satisfied since the value of production for each industry is equal to its total costs of production (the sum of intermediate inputs plus labour and capital costs. indirect taxes paid minus subsidies received). These same components are present for each of the other regions' commodity and industry accounts.

Table 3 presents summary data on regional domestic and external transactions. Each region is in overall balance in its transactions with other regions, the rest of the world and the federal government. Each regions' imbalance in production and demand in the regional account, (the value of the regional trade surplus or deficit) is fully offset by the difference between region's payments and receipts to and from the federal government. The table also displays the relative importance of each region's production and expenditure in relation to the national aggregates.

Federal government taxes collected and cash expenditures by region are reported in Table 4 along with estimates of transfer payments. The significance of federal government activities in each region is reflected in the size of the surplus or deficit reported, and the relative size of government purchases of goods and services in each region. The pattern of regional deficits and surpluses changes substantially when implicit taxes and 


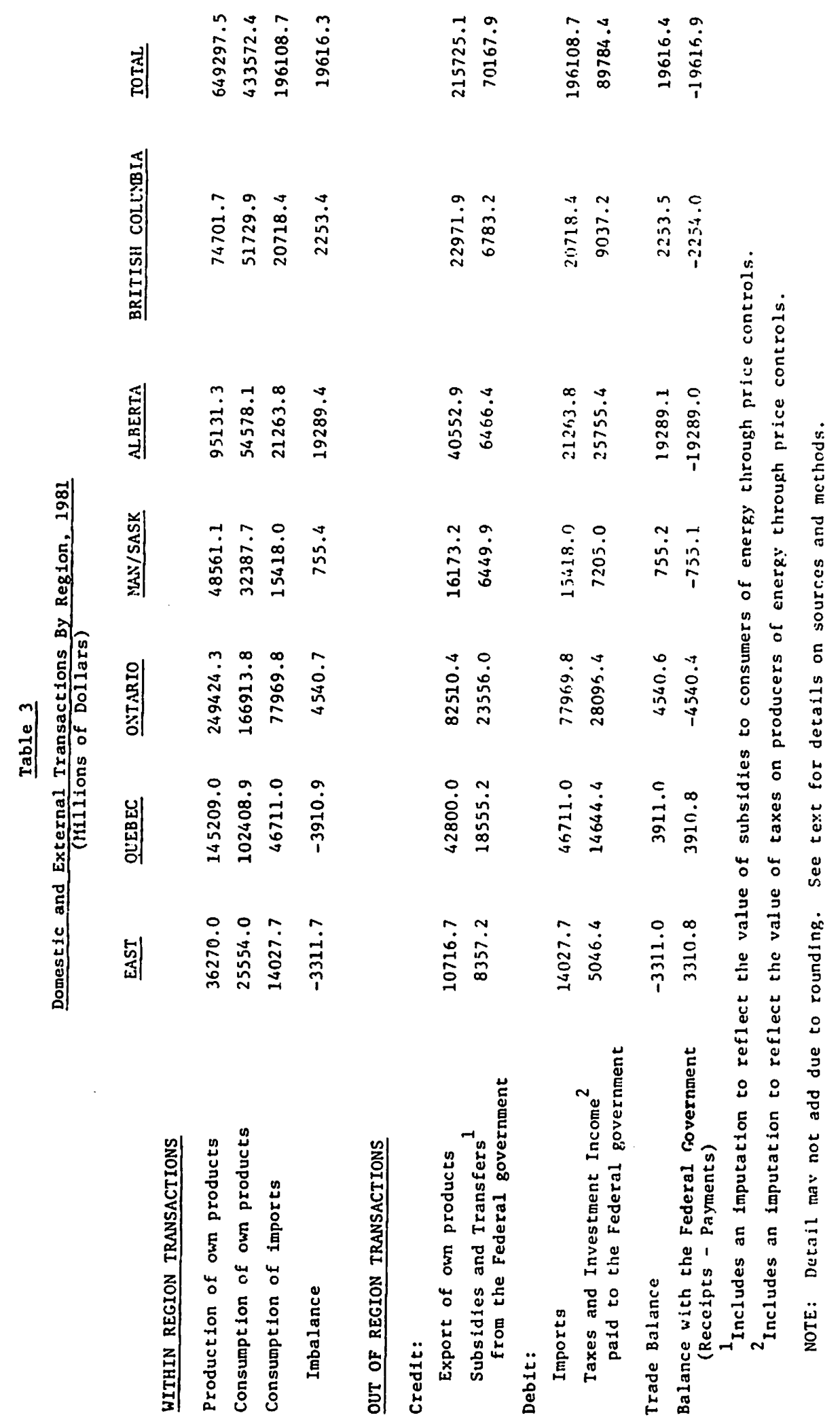




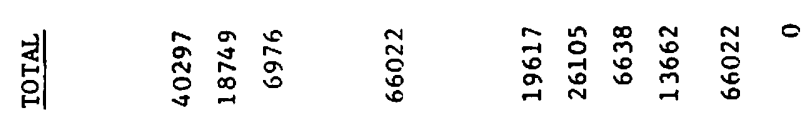

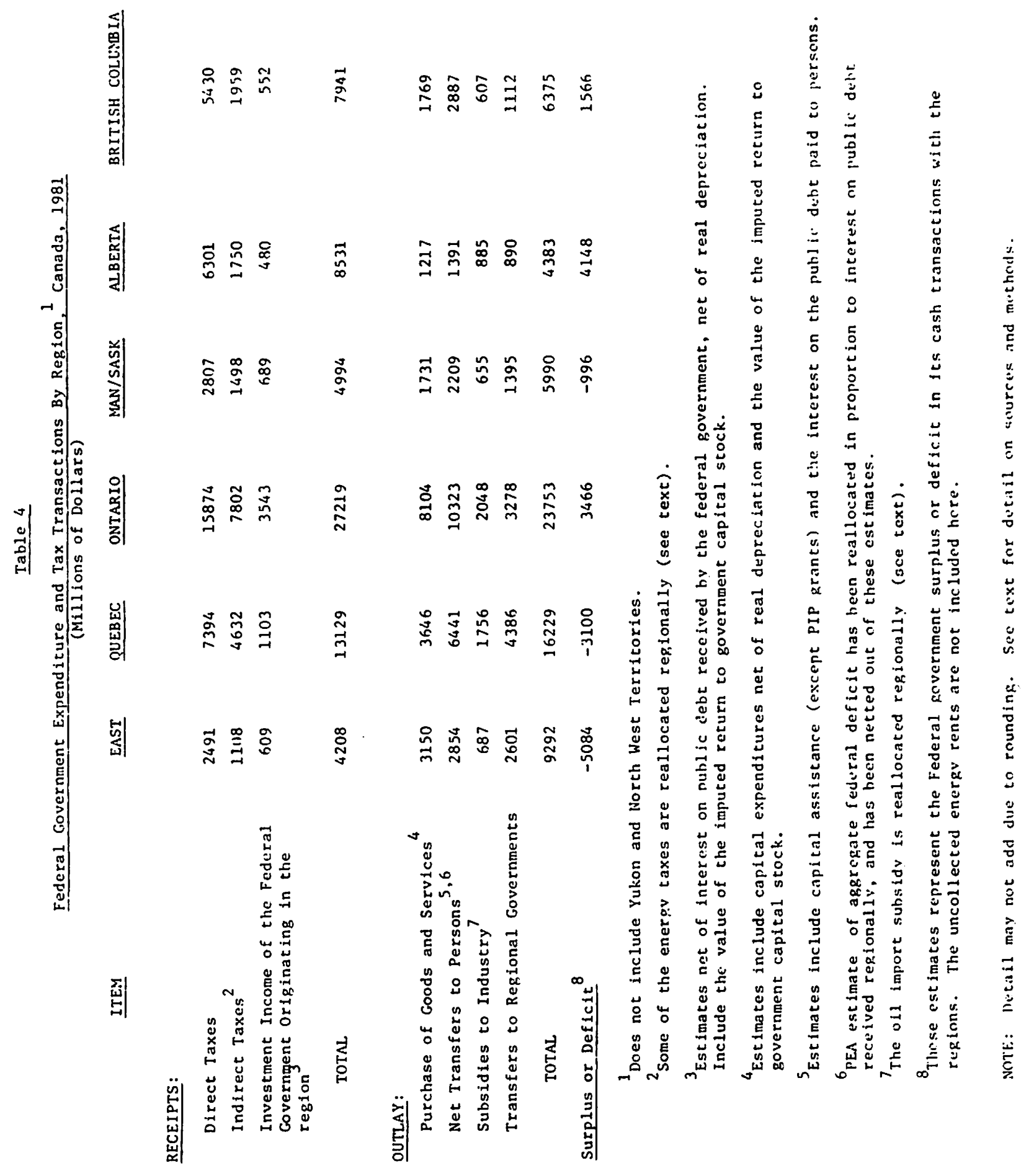


subsidies in the energy sector are taken into account, as reflected in Table 3 .

Finally Table 5 reports the pattern and the size of trade flows both among regions, and between regions and the rest of the world. This table also provides estimates of international and interregional trade deficits or surplus by region. Ontario and Quebec run surpluses on interregional trade, but deficits on international trade. B.C. and Manitoba/Saskatchewan show opposite imbalances on these flows. Atlantic Canada has a deficit and Alberta a surplus on both accounts.

The microconsistent data set summarized in these tables has already provided input for both regional general equilibrium analysis and partial equilibrium evaluations of interregional impacts of various government policies. (See Trela and whalley $(1985))$

\section{Conclusion}

This paper describes the sources and methods used in constructing a regional micro-consistent data set for Canada for 1.981 and reports some of the main features of this data in a series of summary tables. The basic characteristics of the regional data set are simjlar to those of the 1972 national data set described in an earlier paper by st-Hilaire and whalley (1983), but with the added complications of regional transactions. We describe existing sources of provincial data, and how these are used in assembling the data set. We also describe the structure of the microconsistent data set, in particular how 


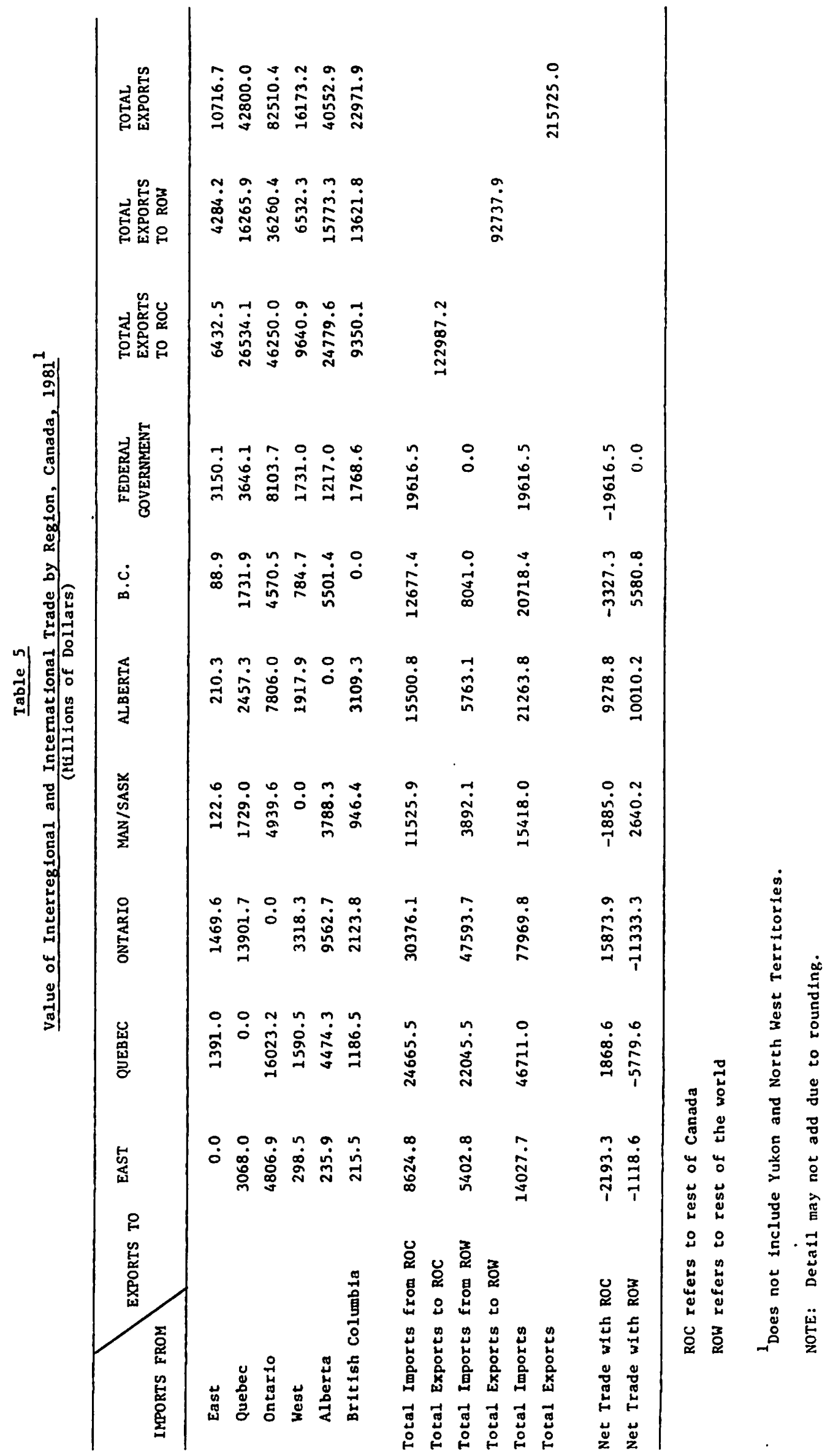


interregional flows of goods and services and the transactions between the federal government and the individual regions are incorporated. Given the continuing interest in regional issues in Canada and elsewhere, data sets of the kind described in this paper can prove useful even outside the context of general equilibrium modelling efforts. 


\section{B I BL I OGRAPHY}

Bacharach, M. Bi-Proportional Matrices and Input-output Change.

Cambridge: Cambridge University Press, 1971.

Economic Council of Canada. Financing Confederation - Today and

Tomorrow. Ottawa: Minister of Supply and Services Canada, 1982.

Energy, Mines and Resources Canada. Financial and Fiscal

Analysis Branch. Petroleum Fiscal Systems in Canada: A

Summary. Ottawa: Energy, Mines and Resources Canada, 1983 .

Petroleum Monitoring Agency Canada. Canadian Petroleum Industry,

Monitoring Survey 1982. Ottawa: Minister of Supply and

Services, Canada, 1983 .

statistics Canada. National Income and Expenditure Accounts,

Vol. 3, Definitions, Concepts, Sources and Methods.

Cat. No. 13-549E. Ottawa: Minister of Supply and Services

Canada, 1975 .

Statistics Canada. Fixed Capital Flows and Stocks, 1983.

Cat. No. 13-211. Ottawa: Minister of Supply and Services

Canada. $1983 a$.

statistics Canada. National Income and Expenditure Accounts,

1968-82. Cat. No. 13-201. Ottawa: Minister of Supply and Services Canada, $1983 \mathrm{~b}$.

statistics Canada. Provincial Economics Accounts, 1966-1981.

Cat. No. 13-213. Ottawa: Minister of Supply and Services

Canada, $1983 \mathrm{C}$. 
Statistics Canada. Corporation Taxation Statistics, 1981.

Cat. No. 61-208. Ottawa: Minister of Supply and Services Canada, $1984 a$.

Statistics canada. The Input-output structure of the canadian Economy, 1971-1980. Cat. No. 12-201E. Ottawa: Minister of Supply and Services Canada, 1984 b.

st-Hilaire, F. and $J$. Whalley. "A Microconsistent Equilibrium Data set for Canada for Use in Tax Policy Analysis." Review of Income and Wealth 29 (June 1983): 175-204.

Trela, I. and J. Whalley. Regional Aspects of Confederation. Research monograph for the Royal Commission on the Economic Union and Development Prospects for Canada, 1985. 


\section{Appendix A}

Aggregated Industry/Commodity classification Used in the Data set

1. Agriculture (grains and other agriculture products)

2. Fishing and trapping

3. Mines and quarries

4. Food, beverages and tobacco (meat, fish and dairy products; fruits and vegetables; miscellaneous food products; beverages; tobacco and tobacco products)

5. Light manufacturing (rubber, leather and plastic products; textile and knitted products; clothing; furniture and fixtures)

6. Lumber, paper and printing (lumber; saw mill and and other wood products; paper and paper products; printing and publishing)

7. Metal and machinery (metal products; machinery and equipment, electrical and communication products; mineral and chemical products; miscellaneous manufacturing products)

8. Vehicles (motor vehicles; motor vehicle parts; other transportation equipment)

9. Energy (mineral fuels; petroleum and coal products)

10. Transportation (transportation and storage; transportation margins)

11. Utilities (electric power and other utilities) 
12. Personal and business services (construction; communication services; wholesale and retail trade; imputed rent on owner occupied dwellings; finance, insurance and real estate; miscellaneous personal and business services)

13. Government services (public administration and defence; other services provided by the public sector) 
$8101 C$

$8102 \mathrm{C}$.

$8103 C$

$8104 C$

$8105 C$

$8106 C$

$8107 \mathrm{C}$

8108C D gJ

8109C D S

$8110 \mathrm{C}$

$8111 C$

$8201 C$

$8202 C$

$8203 \mathrm{C}$

$8204 \mathrm{C}$

$8205 C$

$8206 C$

$8207 \mathrm{C}$

$8208 C$

Markusen, James R. Factor Movements and Commodity Trade as Compliments: A Survey of some Cases.

Conlon, R.M. Comparison of Australian and Canadian Manufacturing Industries: some Empirical Evidence.

Conlon, R.M. The Incidence of Transport Cost and Tariff Protection: Some Australian Evidence.

Laidler, David. On the Case for Gradualism.

Wirick, Ronald G. Rational Expectations and Rational

Stabilization Policy in an Open Economy

Mansur, Ahsan and John Whalley Numerical Secification of Applied General Equilibrium Models: Estimation, Calibration, and Data.

Burgess, David F., Energy Prices, Capital Formation, and Potential GNP

Jimenez, E. and Douglas $\mathrm{H}$ Keare. Housing Consumption and I ncome in the Low Income Urban Setting: Estimates from Panel Data in El Salvador

Whalley, John Labour Migration and the North-South Debate'

Manning, Richard and John McMillan Government Expenditure: and Comparative Advantage

Freid, Joel and Peter towitt Why Inflation Reduces Real I niterest Rates

1982

Manning, Richard and James R. Markusen Dynamic Non-Substitution and Long Run Production Possibilities

Feenstra, Robert and Ken Judd Tariffs, Technology Transfer, and Welfare

Ronald $W$. Jones, and Douglas D. Purvis: International Differences in Response to Common External Shocks: The Role of Purchasing Power Parity

James A Brander and Barbara J. Spencer: Industrial strategy with Committed Firms

Whalley, John, The North-South Debate and the Terms of Trade: An Applied General Equilibrium Approach

Roger Betancourt, Christopher Clague, Arvind Panagariya CAPI TAL UTILIZATION IN GENERAL EQUILIBRIUM

Mansur, Ahsan $H_{6}$ On the Estimation of Import and Export Demand Elasticities and Elasticity Pessimism.

Whalley, J. and Randy Wigle PRICE AND QUANTITY RIGIDITIES IN ADJUSTMENT TO TRADE POLICY CHANGES: ALTERNATIVE FORMULATIONS AND INITIAL CALCULATIONS

8209C DSU JImenez, E. SQUATTING AND COMMUNITY ORGANIZATION IN DEVELOPING COUNTRIES: A CONCEPTUAL FRAMEWORK 
8210C Grossman, G.M. INTERNATIONAL COMPETITION AND THE UNIONIZED SECTOR

8211C LaIdler,D. FRIEDMAN AND SCHWARTZ ON MONETARY TRENDS - A REVIEW ARTICLE 8212C Imam, M.H: and Whalley, J. INCIDENCE ANALYSIS OF A SECTOR SPECIFIC MINIMUM
WAGE IN A TWO SECTOR HARRIS-TODARO MODEL.

8213C Markusen, J.R. and Melvin, J.R. THE GAINS FROM TRADE THEOREM WITH INCREASING
RETURNS TO SCALE.

8214C INDUSTRIAL ORGANIZATION AND THE GENERAL EQUILIBRIUM COSTS OF PROTECTION IN
SMALL OPEN ECONOMIES.

8215C Laldler, D. DID MACROECONOMICS NEED THE RATIONAL EXPECTATIONS REVOLUTION?

8216C Whalley, J. and Wigle, R. ARE DEVELOPED COUNTRY MULTILATERAL TARIFF

8217C Bade, R, and Parkin, M IS STERLING MB IHE RIGHT AGCEGAE?

8218C Kosch, B. FIXED PRICE EQUIILIBRIA IN OPEN ECONOMIES.

1983

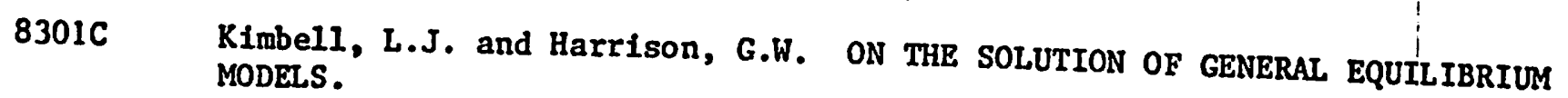

8302C Melvin, J.R. A GENERAL EQ̨UILIBRIUM ANALYSIS OF.CANADIAN OIL POLICY.

$8303 \mathrm{C}$ Markusen, J.R. and Svensson, L.E.0. TRADE IN GOODS AND FACTORS WITH

8304C Mohammad, S. Whalley, J. RENT SEEKING IN INDIA: ITS COSTS AND POLICY
SIGNIFICANCE.

8305C DSU J1menez, E. TENURE SECURITY AND URBAN SQUATTING.

8306C Parkin, M. WHAT CAN MACROECONOMIC THEORY TELL US ABOUT THE WAY DEFICITS
SHOULD BE MEASURED.

8307C Parkin, M. THE INFLATION DEBATE: AN ATTEMPT TO CLEAR THE AIR.

8308C Wooton, I. LABOUR MIGRATION IN A MODEL OF NORTH-SOUTH TRADE.

8309C Deardorff, A.V. THE DIRECTIONS OF DEVELOPING COUNTRIES TRADE: EXAMPLES
FROM PURE THEORY.

8310C Manning, $R$. ADVANTAGEOUS REALLOCATIONS AND MULTIPLE EQUILIBRIA: RESULTS
FOR THE THREE-AGENT TRANSFER PROBLEM. 
$8311 C$ DSU Mohammad, S. and Whalley, J. CONTROLS AND THE INTERSECTORAL TERMS OF TRADE IN INDIA.

8312C . Brecher, Richard A. and Choudhri, Ehsan U. NEW PRODUCTS AND THE FACTOR CONTENT OF INTERNATIONAL TRADE.

8313C Jones, R.W., Neary, J.P. and Ruane, F.P. TWO-WAY CAPITAL FLOWS: CROSSHAULING IN A MDDEL OF FOREIGN INVESTMENT.

$8314 C$ DSU Follain, J.R. Jr. and Jimenez, E. THE DEMAND FOR HOUSING CHARACTERISTICS IN DEVELOPING COUNTRIES.

8315C Shoven, J.B. and Whalley, J. APPLIED GENERAL EQUILIBRIUM MODELS OF TAXATION AND INTERNATIONAL TRADE.

8316C Boothe, Paul and Longworth David. SOME IRREGULAR REGULARITIES IN THE CANADIAN/U.S. EXCHANGE MARKET.

$8317 \mathrm{C}$ Hamilton, Bob and Whalley, John. BORDER TAX ADJUSTMENTS AND U.S. TRADE.

8318C Neary, J. Peter, and Schweinberger, Albert G. FACTOR CONTENT FUNCTIONS AND THE THEORY OF INTERNATIONAL TRADE.

8319C Veall, Michael R. THE EXPENDITURE TAX AND PROGRESSIVITY.

8320C Melvin, James R. DOMESTIC EXCHANGE, TRANSPORTATION COSTS AND INTERNATIONAL TRADE.

8321C Ham1lton, Bob and Whalley, John. GEOGRAPHICALLY DISCRIMINATORY TRADE ARRANGEMENTS .

8322C Bale, Harvey Jr. INVESTMENT FRICTIONS AND OPPORTUNITIES IN BILATERAL U.S.-CANADIAN TRADE RELATIONS.

8323C Wonnacott, R.J. CANADA-U.S. ECONOMIC RELATIONS-A CANADIAN VIEW.

8324C Stern, Robert M. U.S.-CANADIAN TRADE AND INVESTMENT FRICTIONS: THE U.S: VIEW.

8325C Harrison, Glenn, H. and Kimbe11, Larry, J. HOW ROBUST IS NUMERICAL GENERAL EQUILIBRIUM ANALYSIS?

8326C Wonnacott, R.J. THE TASK FORCE PROPOSAL ON AUTO CONTENT: WOULD THIS SIMPLY EXTEND THE AUTO PACT, OR PUT IT AT SERIOUS RISK?

8327C Bradford, James C. CANADIAN DEFENCE TRADE WITH THE U.S. Conklin, David. SUBSIDY PACTS.

Rugman, Alan M. THE BEHAVIOUR OF U.S. SUBSIDARIES IN CANADA:

IMPLICATIONS FOR TRADE AND INVESTMENTS. 


\begin{abstract}
8328C Boyer, Kenneth D. U.S.-CANADIAN TRANSPORTATION ISSUES.
$8329 \mathrm{C}$ Bird, Richard M. and Brean, Donald J.S. CANADA-U.S. TAX RELATIONS: ISSUES AND PERSPECTIVES.

$8330 \mathrm{C}$ Moroz, Andrew R. CANADA-UNITED STATES AUTOMOTIVE TRADE AND TRADE POLICY ISSUES.

8331C Grey, Rodney de C. and Curtis, John. INSTITUTIONAL ARRANGEMENTS FOR U.S.-CANADIAN NEGOTIATIONS. PART I: CANADA-U.S. TRADE AND ECONOMIC ISSUES: DO WE NEED A NEW INSTITUTION? PART II: INSTITUTIONAL ARRANGEMENTS FOR MANAGING THE CANADA-U.S. ECONOMIC RELATIONSHIP.
\end{abstract}

\title{
$\underline{1984}$
}

8401C Harrison, Glenn w. and Manning, Richard. BEST APPROXIMATE AGGREGATION OF INPUT-OUTPUT SYSTEMS.

8402C Parkin, Michael. CORE INFLATION: A REVIEW ESSAY.

$8403 \mathrm{C}$ Blomqvist, Ảke, and McMahon, Gary. SIMULATING COMMERICAL POLICY IN A SMALL, OPEN DUAL ECONOMY WITH URBAN UNEMPLOYMENT: A GENERAL EQUILIBRIUM APPROACH.

$8404 \mathrm{C}$ Wonnacott, Ronald. THE THEORY OF TRADE DISCRIMINATION: THE MIRROR IMAGE OF VINERIAN PREFERENCE THEORY?

$8405 \mathrm{C}$ Whalley, John. IMPACTS OF A 50\% TARIFF REDUCTION IN AN EIGHT-REGION GLOBAL TRADE MODEL.

8406C Harrison, Glenn W. A GENERAL EQUILIBRIUM ANALYSIS OF TARIFF REDUCTIONS.

8407C Horstmann, Ignatius and Markusen, James R. STRATEGIC INVESTMENTS AND THE DEVELOPMENT OF MULTINATIONALS.

8408C Gregory, Allan $W$. and McCurdy, Thomas H. TESTING THE UNBIASEDNESS HYPOTHESIS IN THE FORIARD FOREIGN EXCHANGE MARKET: A SPECIFICATION ANALYSIS.

$8409 \mathrm{C} J o n e s$, Ronald $W$. and Klerzkowsk1, Henryk. NEIGHBORHOOD PRODUCTION STRUCTURES WITH APPLICATIONS TO THE THEORY OF INTERNATIONAL TRADE.

$8410 \mathrm{C}$ Weller, Paul and Yano, Makoto. THE ROLE OF FUTURES MARKETS IN INTERNATIONAL TRADE: A GENERAL EỌUILIBRTUM APPROACH.

$8411 \mathrm{C}$ Brecher, Richard A. and Bhagwat1, Jagdish N. VOLUNTARY EXPORT RESTRICTIONS VERSUS IMPORT RESTRICTIONS: A WELFARE-THEORETIC COMPARISON. 
$8412 \mathrm{C}$ Ethier, wilfred J. ILLEGal IMMIGRATION.

$8413 \mathrm{C}$ Eaton, Jonathon and Gene M. Grossman. OPTIMAL TRADE AND INDUSTRIAL POLICY UNDER OLIGOPOLY.

$8414 \mathrm{C}$ Wooton, Ian. PREFERENTIAL TRADING AGREEMENTS - A 3xn MODEL.

$8415 \mathrm{C}$ Parkin, Michael. DISCRIMINATING BETWEEN KEYNESIAN AND CLASSICAL THEORIES OF THE BUSINESS CYCLE? JAPAN 1967-1982

8416C Deardorff, Alan V. FIRless FIRwoes: HOW PREFERENCES CAN INTERFERE WITH THE THEOREMS OF INTERNATIONAL TRADE.

8417C Greenwood, Jeremy. NONTRADED GOODS, THE TRADE BALANCE, AND THE BALANCE OF PAYNENTS.

8418C Blomqvist, Ake and Sharif Mohammad. CONTROLS, CORRUPTION, AND COMPETITIVE RENT-SEEKING, IN LDCs.

8419C Grossman, Herschel I. POLICY, RATIONAL EXPECTATIONS, AND POSITIVE ECONOMIC ANALYSIS.

8420C Garber, Peter M. and Robert G. King. DEEP STRUCTURAL EXCAVATION? A CRITIOUE OF EULER EQUATION METHODS.

8421C Barro, Robert J. THE BEHAVIOR OF U.S. DEFICITS.

8422C Persson, Torsten and Lars E.0. Svensson. INTERNATIONAL BORROWING AND TIME-CONSISTENT FISCAL POLICY.

8423C Obstfeld Maurice. CAPITAL CONTROLS, THE DUAL EXCLANCE RATE, AND DEVALUATION.

8.24C Kuhn, Peter. UNION PRODUCTIVITY EFFECTS AND ECONOMIC EFFICIENCY.

8425C Hamilton, Bob and John Whalley. TAX TREATMENT OF HOUSING IN A DYNAMIC SEOUENCED GENERAL EOUUILIBRIUM MODEL.

$\because 426 \mathrm{C}$ Hamilton, Bob, Shartf Mohammad, and John Whalley. RENT SEEKING AND THE NORTH-SOUTH TERMS OF TRADE.

8427C Adams, Charles and Jeremy Greenwood. DUAL EXCHANGE RATE SYSTEMS AND CAPITAL CONTROLS: $\Lambda$ N INVESTIGATION.

3428 Loh, Choon Cheong and Michael R. Veall. A NOTE ON SOCIAL SECURITY AND PRIVATE SAVINGS IN SINGAPORE.

8429 Whalley, John. REGRESSION OR PROCRESSION: THE TAXING OUESTION OF INCIDENCE ANALYSIS.

8430 Kuhn, Peter. WAGES, EFFORT, AND INCENTIVE-COMPATIBILITY IN LIFE-CYCLE EMPLOYMENT CONTRACTS. 
8431 Greenwood, Jeremy and Kent P. Kimbrough. AN INVESTIGATION IN THE THEORY OF FOREIGN EXCHANGE CONTROLS.

8432 Greenwood, Jeremy and Kent P. Kimbrough. CAPITAL CONTROLS AND THE INTERNATIONAL TRANSMISSION OF FISCAL POLICY.

8433 : Nguyen, Trien Trien and John Whalley. EỌUILIBRIUM UNDER PRICE CONTROLS WITH ENDOGENOUS TRANSACTIONS COSTS.

8434 Adams, Charles and Russell S. Boyer. EFFICIENCY AND A SIMPLE MODEL OF EXCHANGE RATE DETERMINATION.

8435 Kuhn, Peter. UNIONS, ENTREPRENEURSHIP, AND EFFICIENCY.

8436 Hercowitz, Zvi and Efraim Sadka. ON OPTIMAL CURRENCY SUBSTITUTION POLICY AND PUBLIC FINANCE.

8437 Lenjosek, Gordon and John Whalley. POLICY EVALUATION IN A SMALL OPEN PRICE TAKING ECONOMY: CANADIAN ENERGY POLICIES.

8438 Aschauer, David and Jeremy Greenwood. MACROECONOMIC EFFECTS OF FISCAL POLICY.

8439C Hercowitz, Zvi. ON THE DETERMINATION OF THE EXTERNAL DEBT: THE CASE OF ISRAEL.

8440C Stern, Robert M. GLOBAL DIMENSIONS AND DETERMINANTS OF INTERNATIONAL TRADE AND INVESTMENT IN SERVICES.

8441C Deardorff, Alan V. COMPARATIVE ADVANTAGE AND INTERNATIONAL TRADE AND INVESTMENT IN SERVICES.

8442C Daly, Donald J. TECHNOLOGY TRANSFER AND CANADA'S COMPETITIVE PERFORMANCE.

8443C Grey, Rodney de C. NEGOTIATING ABOUT TRADE AND INVESTMENT IN SERVICES.

8444C Grossman, Gene M. and Carl Shapiro. NORMATIVE ISSUES RAISED BY INTERNATIONAL TRADE IN TECHNOLOGY SERVICES.

3445C Chant, John $\mathrm{F}$. THE CANADIAN TREATMENT OF FOREIGN BANKS: A CASE STUDY IN THE WORKINGS OF THE NATIONAL TREATMENT APPROACH.

8446C Aronson, Jonathan D. and Peter F. Cowhey. COMPUTER, DATA PROCESSING, AND COMMUNICATION SERVICES.

8447C Feketekuty, Geza. NEGOTIATING STRATEGIES FOR LIBERALIZING TRADE AND INVESTMENT IN SERVICES.

8448C Harrison, Glenn, W. and E.E. Rutstrom. THE EFFECT OF MANUFACTURING SECTOR PROTECTION ON ASEAN AND AUSTRALIA: A GENERAL ENUILIBRIUM ANALYSIS. 
$8501 \mathrm{C}$

8502C Horstmann, Ignatius and James R. Markusen. UP YOUR AVERAGE COST CURVE: INEFFICIENT ENTRY AND THE NEW PROTECTIONISM.

8503C Gregory, Allan W. TESTING INTEREST RATE PARITY AND RATIONAL EXPECTATIONS TOR CANADA AND THE UNITED STATES.

8504C Kuhn, Peter and Ian Hooton. INTERNATIONAL FACTOR MOVEMENTS IN THE PRESENCE OF A FIXED FACTOR.

8505C Wong, Kar-yiu. GAINS FROM GOODS TRADE AND FACTOR MOBILITY.

8506C Heller, Paul and Makoto Yano. FUTURES MARKETS, REAL INCOME, AND SPOT PRICE VARIABILITY: A GENERAI EOUUILIBRIUM APPROACH.

8507C Diewert, H.E. THE EFFECTS OF AN INNOVATION: A TRADE THEORY APPROACH.

8508C Ethier, Wilfred J. FOREIGN DIRECT INVESTMENT AND THE MULTINATIONAL FIRM.

8509C Dinopoulos, Elias. INSIDE THE BLACK BOX: (IN)TANGIBLE ASSETS, INTRA-INDUSTRY INVESTMENT AND TRADE.

8510C Jones, Richard, John Whalley, and Randall Higle. REGIONAL IMPACTS OF TARIFFS IN CANADA: PRELIMINARY RESULTS FROM A SMALL DIMENSIONAL NUMERICAL GENERAL EOUUILIBRIUM MODEL.

8511C Whalley, John. HIDDEN CHALLENGES IN RECENT APPLIED GENERAL EOQUILIBRIUM EXERCISES.

8512C Smith, Bruce. SOME COLONIAL EVIDENCE ON TWO THEORIES OF MONEY: MARVLAND AND THE CAROLINAS.

3513C Grossman, S.J., A. Melino, and R.J. Shiller. ESTIMATING THE CONTINUOUS TIME CONSUMPTION BASED ASSET PRICING MODEL.

8514C Romer, Paul R. TAX EFFECTS AND TRANSACTION COSTS FOR SHORT TERM MARKET DISCOUNT BONDS.

8515C McCallum, Bennett T. ON CONSEOUENCES AND CRITJCISMS OF MONETARY TARGETING.

8516C Dinopoulos, Elias and Ian Wooton. A NORTH-SOUTH MODEL OF INTERNATIONAL JUSTICE.

8517C Huffman, Gregory W. A DYNAMIC EQUILIBRIUM MODEL OF ASSET PRICES AND TRANSACTION VOLUME.

8518C Huffman, Gregory W. AN ALTERNATIVE VIEW OF OPTIMAL SEIGNIORAGE.

8519C Huffman, Gregory W. ASSET PRICING WITH HETERGENEOUS ASSETS. 
8520C Hercowitz, Zvi. THE REAL INTEREST RATE AND AGGREGATE SUPPLY.

8521C Davies, James and Michael Hoy. COMPARING INCOME DISTRIBUTIONS UNDER AVERSION TO DOWNSIDE INEQUALITY.

8522C Nguyen, Trien $\mathrm{T}$. and John Whalley. COEXISTENCE OF EQUILIBRIA ON BLACK AND WHITE MARKETS.

8523C Clarete, Ramon and John Whalley. INTERACTIONS BETWEEN TRADE POLICIES AND DOMESTIC DISTORTIONS: THE PHILIPPINE CASE.

8524C Hamilton, Bob, Sharif Mohammad, and John Whalley. APPLIED GENERAL EQUILIBRIUM ANALYSIS AND PERSPECTIVES ON GROWTH PERFORMANCE.

8525C Huffman, Gregory $W$. THE LAGGED EFFECTS OF POLICY ON THE PRICE LEVEL.

8526C Laidler, David. FISCAL DEFICITS AND INTERNATIONAL MONETARY INST ITUTIONS.

8527C Goodfriend, Marvin. MONETARY MYSTIQUE: SECRECY AND CENTRAL BANKING.

8528C Nguyen, Trien T. and John Whalley. GENERAL EQUILIBRIUM ANALYSIS OF PRICE CONTROLS A TWO-SECTOR COMPUTATIONAL APPROACH.

$8529 \mathrm{C}$ Heckman, James $\mathrm{J}$. and V. Joseph Hotz. AN INVESTIGATION OF THE LABOR MARKET EARNINGS OF PANAMANIAN MALES: EVALUATING SOURCES OF INEQUALITY.

8530C Greenwood, Jeremy and Gregory W. Huffman. A DYNAMIC EQUILIBRIUM MODEL OF INFLATION AND UNEMPLOYMENT.

8531C Freeman, Scott. INSIDE MONEY, MONETARY CONTRACTIONS, AND WELFARE.

8532C Paderanga, Cayetano Jr. and Ian Wooton. A POSITIVE VIEW OF INFANT INDUSTRIES.

8533C St-Hilaire, France and John Whalley. A MICROCONSISTENT DATA SET FOR CANADA FOR USE IN REGIONAL GENERAL EQUILIBRIUM POLICY ANALYSIS. 